\title{
Projection of the Demand of Electricity in the State of Paraná for 2050 and Proposal of Complementarity of the Electrical Matrix through the Solar Photovoltaic Source
}

\author{
Arileide Cristina Alves ${ }^{1 *}$, Renata Lautert Yang ${ }^{1}$, Gerson Máximo Tiepolo ${ }^{1}$ \\ ${ }^{1}$ Universidade Tecnológica Federal do Paraná, Curitiba, Paraná, Brasil.
}

\begin{abstract}
Energy is essential for human activities and, considering the prospect that the demand for energy increases, it is necessary to carry out studies of new technical solutions so as to make the use of the available sources feasible. Greater participation of renewable energy sources in the electricity matrix has been stimulated worldwide and a number of public policies have been adopted by different countries in order to seek greater energy security and sustainability. In this context, photovoltaic solar energy potentially plays an important role in the evolution of the participation of alternative sources in the world energy matrix, considering its abundance and wide availability in the terrestrial surface. This work proposes a methodology to model a scenario that estimates the consumption of electricity in 2050 in the State of Paraná and how it can contribute to the complementarity of the Brazilian electricity matrix. In addition, it indicates, based on decision factors, which are the most indicated mesoregions for possible deployments of grid-connected photovoltaic systems in Paraná to meet this demand.
\end{abstract}

Key words: Energy Consumption 2050, Complementarity, Energy Planning, Photovoltaic Solar Energy, Mesoregions of Paraná.

*Author of correspondence: arileide.c.alves@gmail.com 


\section{INTRODUCTION}

According to ${ }^{1}$, there are over 300 different definitions for the term 'sustainability', this being the result of the perception of a global environmental crisis. One of the possible interpretations of sustainability may be the perception of the finiteness of natural resources and their gradual and dangerous depletion, which undoubtedly requires greater attention in how to reconcile the preservation of the environment and economic development. This intention is commonly called "Sustainable Development" ${ }^{2}$. Both the expression and the definition of sustainable development became popularized and inserted in political agenda from 1987, with the publication of the Brundtland Report. This report does not present a way to operationalize the concept of Sustainable Development. Its main lines reveal a contract between generations, emphasizing that economic and social progress cannot be based on the indiscriminate and devastating exploitation of nature ${ }^{3}$. However, it is clear that growth always means some form of environmental degradation and physical loss ${ }^{4}$.

In this context, since energy is essential for human activities, and considering the prospect that the demand for energy increases, it is necessary to develop new technical solutions to make the use of available sources feasible in order to mitigate environmental problems and ensure satisfactory service for society. According to the MME study on energy demand in Brazil in 2013-2050 , there will be a significant increase in energy consumption, as shown in Figure 1.

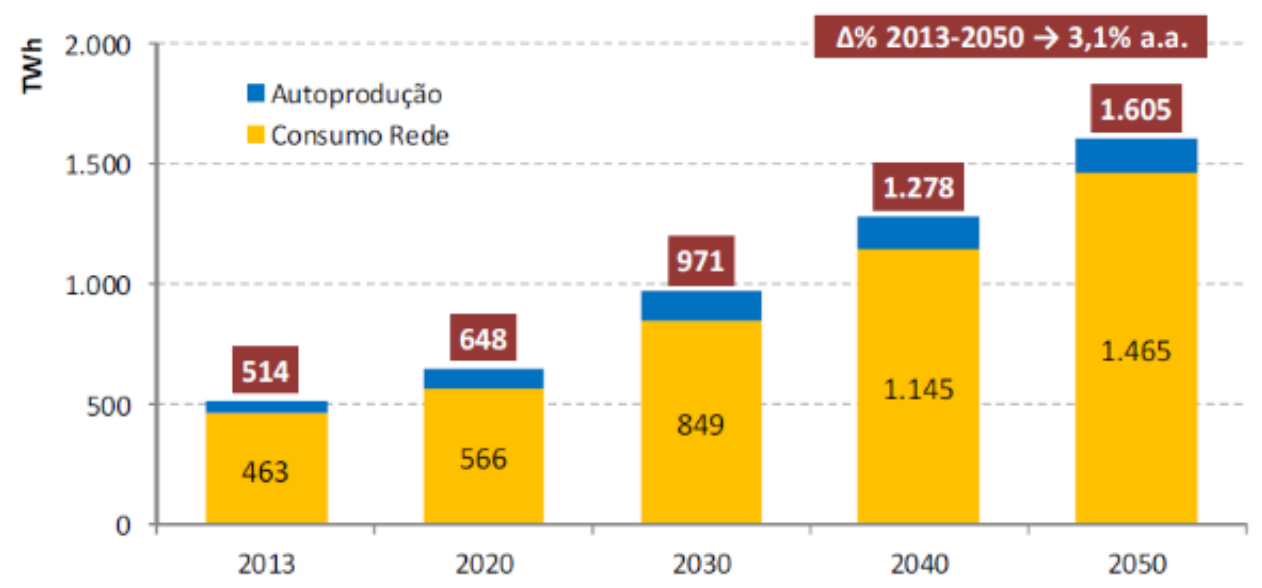

Figure 1 - Total electricity consumption in Brazil in TWh / year, 2013-2050

Observing Figure 1, it can be noted that the electricity consumption of the grid will increase by $216 \%$, going from 463 TWh in 2013 to 1,465 TWh in 2050. It is also noticed that the self-production of electricity will increase by $180 \%$, going from $51 \mathrm{TWh}$ in 2013 to 140 TWh in 2050. With regard to the production of electricity in Brazil, the state of Paraná is the largest producer through hydric source, due to the large existing hydrographic basin ${ }^{6}$. However, difficulties in the exploration of hydric potential, whether of a political and / or environmental nature, impel the analysis and application of other sources of energy. In addition, the difficulty of expanding sources that use fossil fuels because of greenhouse gases and consequently contribute to global warming, coupled with the increasing demand for electricity, will increase the use of renewable energy sources.

Based on the above considerations, it is necessary to analyze the conditions in Brazil, in order to carry out a prospection and study in this area. As published in ${ }^{7}$, the domestic supply of electric energy qualitatively and quantitatively has its varieties. However, solar energy is among the least used sources, despite its high potential. Higher 
investments in photovoltaic energy can leverage a successful work, in the sense that this type of source can act in a more expressive way in the complementariness and attendance to the demand of distributed form, postponing investments in transmission and distribution of electric energy.

In order to invest in photovoltaic solar energy in Brazil, it can be argued that the solar radiation received in the country annually is extremely favorable, as shown in Figure 2. It is possible to notice in this map that the state of Paraná is in a place of great potential for the implementation of this energy source, since it receives high solar irradiation in much of its territory.

Regarding the generation of electricity through photovoltaic systems, it can be stated that the National Interconnected System (SIN) currently has two types of generating subsystems: centralized generation, composed of large power plants that are normally distant from the consumer centers, and distributed generation, where the supply is made through small power plants through micro and mini generation installed in the same consumers or near them. There are smaller systems, which are not connected to the SIN, such as the isolated systems that are located in the most remote regions of the country, such as the Northern region of Brazil, where there is no possibility of connection to the national system due to the economic unfeasibility imposed by distance or environmental issues $^{8}$.

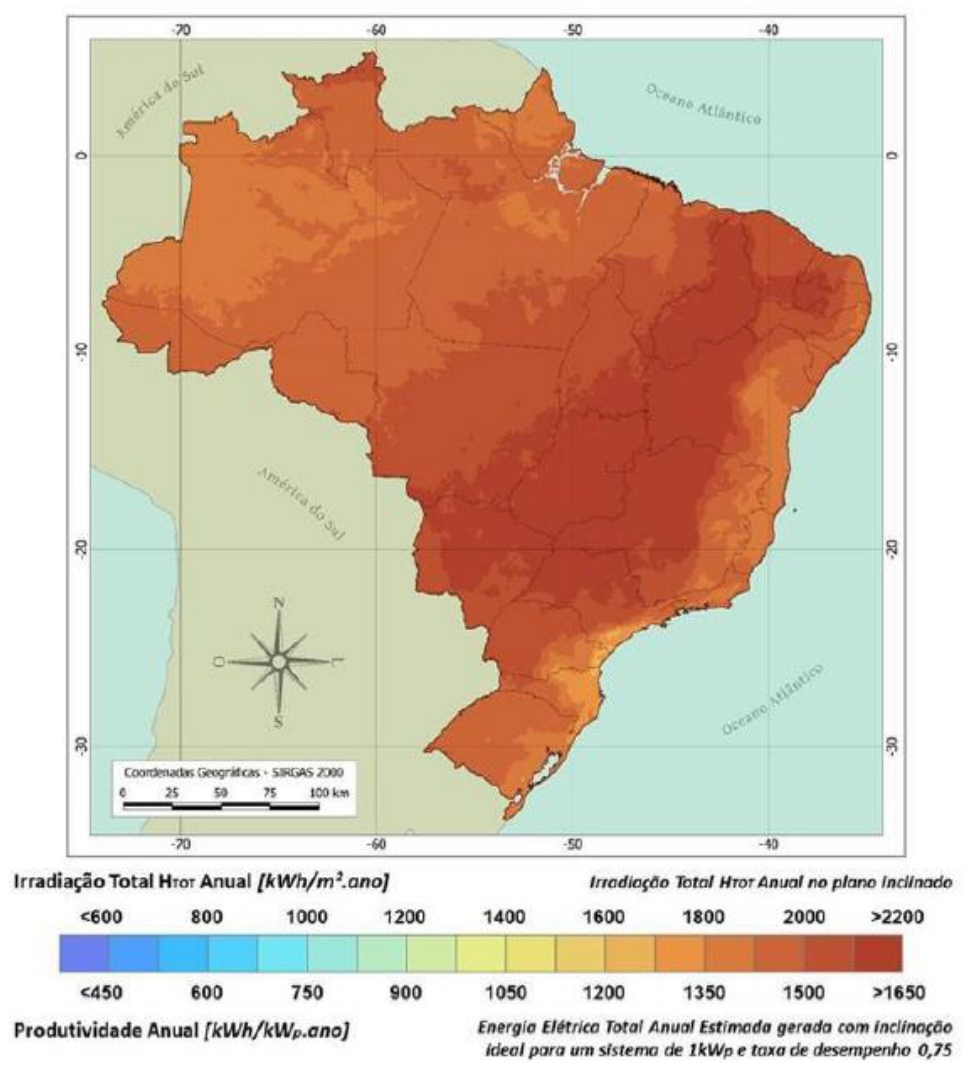

Figure 2 - Brazilian Photovoltaic Map - Annual Total ${ }^{6}$

Considering these facts, regarding the increasing demand for energy and the feasibility of using the photovoltaic source in Brazil, it is important to plan the energy sector in order to "ensure the continuity of energy supply to society at the lowest cost, with the lowest risk of shortages, and with the lowest socio-economic and environmental impacts"'. Thus, planning for the determination of the participation of the state of Paraná 
in the complementation of the national electric matrix through photovoltaic systems is extremely relevant in the current context.

\section{METHODS}

Brazil is a country of continental dimensions. For this reason, the description its territorial division, according to the rules devised by the Brazilian Institute of Statistics and Geography (IBGE), presents six hierarchical levels, which approach from the whole country to the municipalities individually. The whole country represents the first level of the hierarchy, the second is the regions, the third the states, the fourth the mesoregions, the fifth the micro regions and the sixth the municipalities. Paraná State presents ten mesoregions ${ }^{10}$, as shown in Table 1 and its geographical distribution is shown in Figure 3.

Table 1- The 10 mesoregions of Paraná State

\begin{tabular}{ll}
\hline $\mathbf{1}$ & Paraná - South Center \\
\hline $\mathbf{2}$ & Paraná - North Central \\
\hline $\mathbf{4}$ & Paraná - Northwest \\
\hline $\mathbf{5}$ & Paraná - West \\
\hline $\mathbf{6}$ & Metropolitan Region of Curitiba \\
\hline $\mathbf{7}$ & Paraná - Eastern Central \\
\hline $\mathbf{9}$ & Paraná - Southeast \\
\hline $\mathbf{1 0}$ & Paraná - North Pioneer \\
\hline
\end{tabular}

In this work, the decision-making factors used to comply with the proposal were the Municipal Human Development Index (IDHM), the number of inhabitants and the consumption of electric energy.

The IDHM, broader than PIB, is a measure composed of three-dimension indicators of human development: longevity, education and income, ranging from 0 to $1^{12}$. The closer to 1 , the better human development.

For each of the 10 mesoregions of Paraná, data were also collected, such as the population in $2010^{13}$ and forecasts for 2016 and $2030^{14}$, and of each of the municipalities belonging to the mesoregion in question.

Based on these data, a curve fit was established to predict the population, yearly, for each municipality, by the year 2050. For prediction up to the year 2050, via linear adjustment, of the consumption of electric energy in each municipality from each of the mesoregions, data from the years $2010^{13}$, from $2013^{15}$ and from $2015^{16}$ were collected and used. The IDHM criterion according to ${ }^{12}$ used the most recent data available from the 2010 census.

The solar irradiance and productivity of each municipality was an additional criterion used to determine the potential of the photovoltaic source for the possibility of complementarity of the Brazilian electric matrix ${ }^{6}$. This value presents variations over the months and, for this reason, the annual values were chosen as they are more representative and so because they are used to estimate the electric energy production by means of Grid-Connected Photovoltaic System (GCPVS). 
The simplest model ${ }^{17}$ that relates two variables $\mathrm{X}$ and $\mathrm{Y}$ is the equation of the line. For any value $\mathrm{x}_{1}$ among the data, the value $\left(\mathrm{y}_{1}\right)$ predicted by the line is $\hat{\mathrm{Y}}_{1}=\mathrm{b}_{0}+\mathrm{b}_{1} \mathrm{x}_{1}$. Consider $d_{1}$ the vertical distance (deviation) of each of these points to the straight line, according to Equation 1:

$$
d_{i}=y_{i}-\widehat{y}_{l}
$$

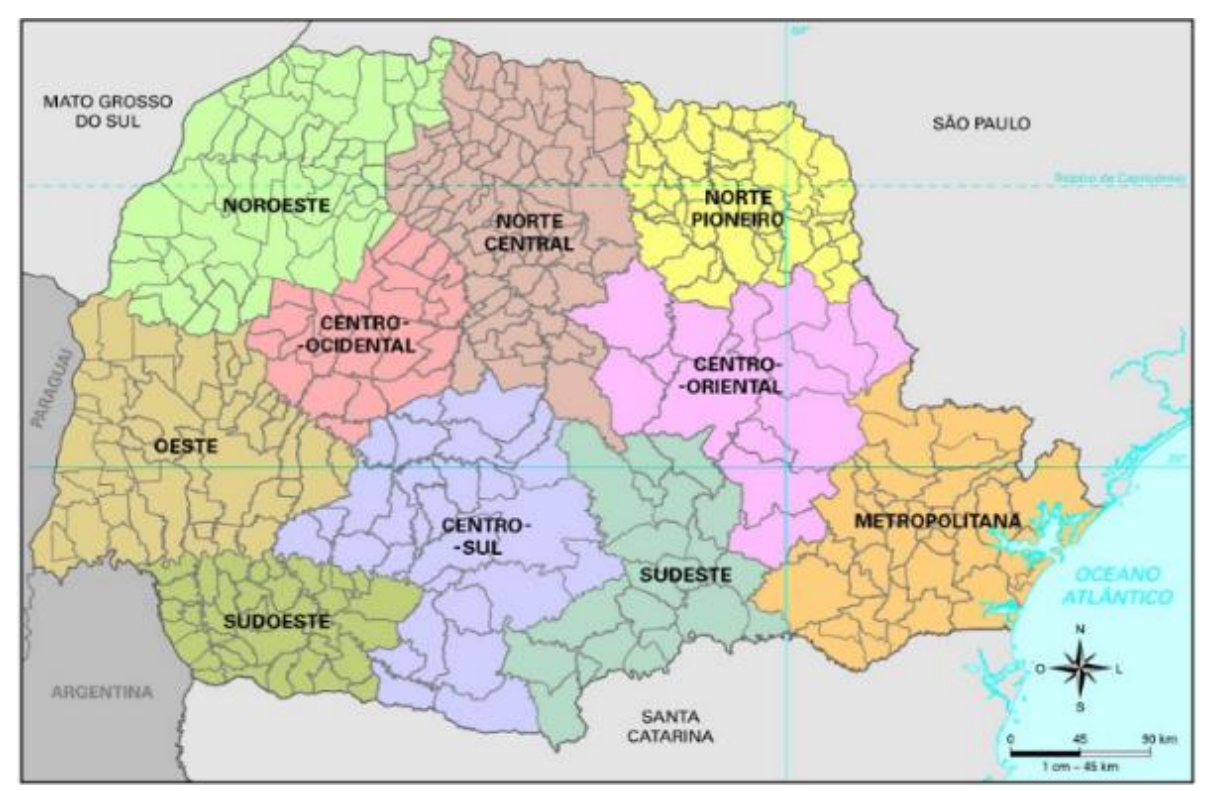

Figure 3 - Distribution of Parana's Mesoregions ${ }^{11}$

Equation 2 shows the measure D of the total deviation when using the arbitrary line for all points considered.

$$
D=\sum_{i=1}^{n} d_{i}^{2}
$$

The magnitude of $\mathrm{D}$ depends on the line used in the chosen linear adjustment, that is, it depends and varies (it is function) according to the coefficients $\beta_{0}$ and $\beta_{1}$, according to Equation 3.

$$
D\left(\beta_{0}, \beta_{1}\right)=\sum_{i=1}^{n}\left(y_{i}-\beta_{0}-\beta_{1} x_{i}\right)^{2}
$$

Among the possibilities, one way of estimating such coefficients is to determine the minimum of Equation 3, which means to equal the first partial derivatives of this function. Assuming the omission of indexes in the sums, for the purposes of simplification of notation, the result can be seen in Equations 4:

$$
\begin{aligned}
& \Sigma \mathrm{y}_{\mathrm{i}}-\Sigma \mathrm{b}_{0}-\Sigma \mathrm{b}_{\mathrm{i}} \mathrm{x}_{\mathrm{i}}=0 \\
& \Sigma x_{i} y_{i}-\Sigma b_{0} x_{i}-\Sigma b_{1} x_{i}^{2}=0
\end{aligned}
$$

The solution of this system of linear equations, also called normal equations, can be obtained by multiplying the first equation by $\Sigma \mathrm{x}_{1} / \mathrm{n}$ and adding it to the second equation, which results in the equivalent system. Through retroactive substitutions, the solution 
of the system is reached through the technique called the Least Square Method ${ }^{18}$. The values $b_{0}$ and $b_{1}$ indicated in Equation 5 are, respectively, the linear and angular coefficients of the line with the smallest possible error, which adapts to the scatter diagram.

$$
\begin{aligned}
b_{1} & =\frac{\mathrm{n} \cdot \Sigma x_{i} y_{i-} \Sigma x_{i} \Sigma y_{i}}{n \cdot \Sigma x_{i}^{2}-\left(\Sigma x_{i}^{2}\right)} \\
b_{0} & =\frac{\Sigma y_{i-}\left(\Sigma x_{i}\right) b_{1}}{n}
\end{aligned}
$$

Once the line presented in Equation 1 is found, it is possible to predict any given data at a desired interval, making sure that the error is minimal. This technique was used to estimate the indicators involved in accomplishing this work.

With the data of population and energy consumption for each municipality of Paraná in 3 distinct years, it was possible to find the first degree polynomial that adapts to such data with the smallest possible error, for each of the municipalities considered. After that, the municipalities were grouped in mesoregions and it was possible to determine the approximate population and energy consumption for each mesoregion for 2010 to 2050.

The proposed empirical method is to find the objective function (FO) image proposed in Equation 6 and determine through the result of this equation, which depends on the energy consumption, the population and the HDI, which are the best places for investments in GCPVS in order to meet this estimated demand.

$$
F O(c, p, i)=(0,75 c+0,20 p+0,05 i)
$$

Where:

$\mathrm{c} \rightarrow$ estimated electricity consumption for 2050 of each mesoregion;

$\mathrm{p} \rightarrow$ average population projected for 2050 of each mesoregion;

$\mathrm{I} \rightarrow$ average of IDHM of each mesoregion.

In order to evaluate the reliability of the coefficients used in the FO, some tests were performed, involving comparatives between the decision parameters and the respective FO image values. Thus, the FO was extended to 5 different evaluations, named: FO1, FO2, FO3, FO4 and FO5. FO1 considered numerical values as indicated in Equation 6. For FO2, the numerical coefficient of "c" took into account the percentage value of increase in electricity consumption, considering the results obtained through Linear Adjustment in 2010 and 2050 for all the mesoregions (or the entire state of Paraná ); the numerical coefficient of " $p$ " took into account, in the same universe, the percentage value of population increase, and the numerical coefficient of "I", the percentage increase in the IDHM in Paraná, considering the 2000 census and the 2010 census which, who registered the values 0.65 and 0.749 respectively ${ }^{19}$.

Since the weights in the case of FO2 are non-scale values, it was necessary to adjust the numerical values of the coefficients in order to harmonize them. To increase energy consumption, the percentage was obtained $119.53 \%$, for the population increase of $28.73 \%$, and for the increase of the IDHM of $15.23 \%$. The values were adjusted using the standard deviation standard, where any new desired value is obtained through Equation 7. After adjustments, these values were replaced in the objective function (FO), for which the image was obtained. 


$$
v n=\frac{v a-m}{\delta}
$$

Where:

$v n \rightarrow$ Adjusted value

$v a \rightarrow$ Old value

$m \rightarrow$ Average of data

$\delta \rightarrow$ Standard deviation between data

FO3 considered the situation where the numerical coefficient of " $p$ " is greater than the value of the numerical coefficient of "I" and, FO4, the situation in which the numerical coefficient of "I" is greater than the value of numerical coefficient of " $p$ ". In these last two cases, the consumption multiplier was considered 0.5 since there is no doubt that it is the preponderant factor in favor of making expansion decisions. The possible values of the numerical coefficients for population and HDI (to be greater or lesser among them) were tested to the extreme, considering among them the minimum difference and which should, together, result in 0.5. The last evaluated case, FO5, is one where the numerical coefficients of "p" and "I" are the same.

It is worth remembering that these numerical coefficients are weights that indicate the degree of relevance of the parameter used (consumption, increase in population or increase in HDI) in FO. The results of this analysis are represented by the functional values of each case of FO evaluated.

\section{RESULTS AND DISCUSSION}

As in the decision factors, the optimal mesoregions for the possible implantation of GCPVS were determined. This decision was made based on the image values of the Objective Function, for each of the 10 mesoregions. It was noticed that the mesoregion that presents greater projection in the consumption is the Metropolitan area of Curitiba and the one with greater deficit of electrical energy will be Paraná - North Central. Looking at the data for the State of Paraná, the forecast indicates that the consumption of electricity in 2050 will be $55.67 \mathrm{TWh}$, approximately $92.92 \%$ higher when compared to the consumption of 2015, which was $28.86 \mathrm{TWh}$.

After the projections were made, the aim was to identify the mesoregions for the implementation of GCPVS, in order to supply the electricity demand for 2050, taking into account the annual irradiance of each mesoregion and the result of the FO, which considers criteria of consumption, population, and IDHM. These two data were placed in the same order of magnitude and then averaged between them to calculate the potential for implantation of GCPVS.

Figure 4 compares the potential of each of the 10 mesoregions (x-axis, as in Table 1), using adjustments of type $\mathrm{x} /$ maximum value ( $\mathrm{y}$-axis). Observing these results, it is concluded that the two most suitable mesoregions for investments in GCPVS are the Paraná - North Central and Metropolitan area of Curitiba, in this order.

Another result of interest consisted in determining the power of the photovoltaic system to complement the growing demand for electric power in Paraná. For that purpose, the data of electrical energy deficit and average productivity for each mesoregion were analyzed. The latter was calculated by averaging the annual productivity in the inclined plane between the cities of each mesoregion of Paraná, considering a performance ratio of $75 \%{ }^{6}$.

After calculations, it was possible to observe that the relatively lower average productivity of the Metropolitan mesoregion of Curitiba, causes the total power of GCPVS to be installed to supply the demand is high, surpassing $3 \mathrm{GWp}$. The Paraná - 
North Central mesoregion, although presenting higher annual productivity, the power to be implemented is also high with a value above $4 \mathrm{GWp}$ due to the large energy deficit presented of approximately 6.5 TWh, against 4.6 TWh in the Metropolitan area of Curitiba. The estimated population, power demand and power of photovoltaic system to be installed in each of the mesoregions are presented in Table 2.

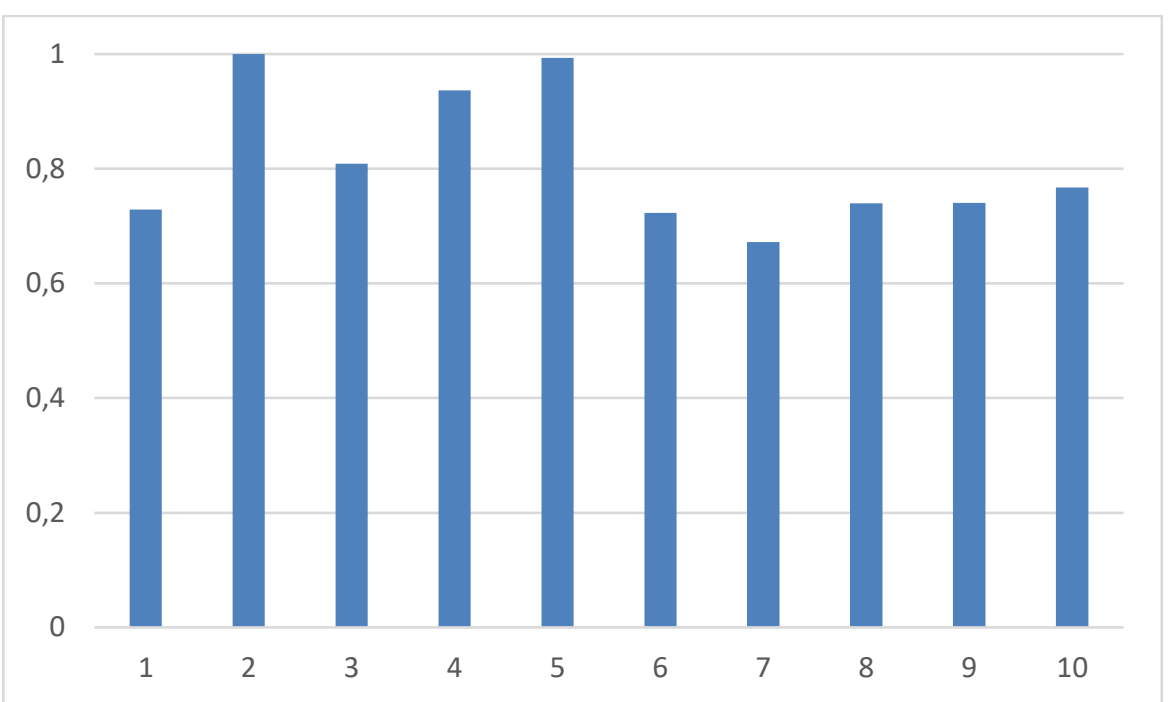

Figure 4 - Photovoltaic complementarity potential of Paraná's mesoregions

Table 2 - Population, consumption and power projections to be installed of GCPVS by 2050

\begin{tabular}{|c|c|c|c|c|c|c|}
\hline Mesoregion & $0<$ IDHM $<1$ & $\begin{array}{c}\text { Projection of } \\
\text { population by } \\
2050 \text { (hab) }\end{array}$ & $\begin{array}{l}\text { Projection of } \\
\text { energy } \\
\text { consumption } \\
\text { by2050 } \\
\text { (MWh) }\end{array}$ & $\begin{array}{c}\text { Electricity } \\
\text { déficit by } \\
2050 \\
(\mathrm{MWh})\end{array}$ & $\begin{array}{c}\text { Average } \\
\text { Annual } \\
\text { Productivity } \\
\text { (kWh/ } \\
\text { kWp) }\end{array}$ & $\begin{array}{c}\text { GCPVS } \\
\text { power to be } \\
\text { deployed by } \\
2050 \text { (MWp) }\end{array}$ \\
\hline $\begin{array}{c}\text { Sem South } \\
\text { Center }\end{array}$ & 0,654 & 557.951 & 2.185 .714 & 1.190 .219 & 1511 & 788 \\
\hline $\begin{array}{c}\text { North } \\
\text { Central }\end{array}$ & 0,714 & 2.441 .353 & 11.812 .624 & 6.481 .360 & 1553 & 4.173 \\
\hline Northwest & 0,705 & 741.906 & 4.599 .903 & 2.985 .896 & 1553 & 1.922 \\
\hline West & 0,717 & 1.364 .364 & 10.162 .741 & 6.364 .278 & 1519 & 4.188 \\
\hline $\begin{array}{c}\text { Metropolitan } \\
\text { of Curitiba }\end{array}$ & 0,693 & 4.364 .798 & 14.658 .886 & 4.553 .720 & 1350 & 3.373 \\
\hline $\begin{array}{l}\text { Eastern } \\
\text { Central }\end{array}$ & 0,689 & 809.843 & 2.426 .737 & -536.686 & 1482 & $\begin{array}{c}\text { There was no } \\
\text { expansion }\end{array}$ \\
\hline Southeast & 0,679 & 450.402 & 2.027 .761 & 1.109 .521 & 1395 & 795 \\
\hline $\begin{array}{c}\text { North } \\
\text { Pioneer }\end{array}$ & 0,702 & 524.319 & 1.884 .024 & 902.437 & 1554 & 581 \\
\hline $\begin{array}{l}\text { Western } \\
\text { Center }\end{array}$ & 0,703 & 308.366 & 2.267 .179 & 1.496 .910 & 1537 & 974 \\
\hline South-west & 0,716 & 538.172 & 3.629 .832 & 2.266 .870 & 1517 & 1.494 \\
\hline
\end{tabular}

The sum of GCPVS powers for the ten mesoregions of Paraná was $18.3 \mathrm{GWp}$ and will be implemented by 2050 to meet the demand of these projections. In addition to the 
generation of energy, this work indicates, in general, the need for investments in transmission and distribution of energy, and which power of GCPVS should be implemented in Paraná in order to supply the future energy consumption in the state.

\section{CONCLUSION}

This work carried out a study of the complementarity of the Brazilian electric matrix in Paraná, through the solar photovoltaic source for 2050. This involved modeling a scenario considering population projections and electric energy consumption for each mesoregion of the State of Paraná. The study can be extended to all Brazilian states, since the levels of geographical division are standardized nationwide.

With data of solar irradiation, prediction of the electric energy consumption and productivity, it was possible to determine the total GCPVS power to be installed. This paper also indicates, based on decision factors, which mesoregions should be the most appropriate for these investments.

The results of this analysis indicated that the most suitable mesoregion for the implantation of GCPVS is the North Central of Paraná, which presents a greater deficit of electric energy by 2050 and a high annual solar irradiation, being $2,071 \mathrm{kWh} / \mathrm{m}^{2}$ /year. The second mesoregion favorable to this implantation is the Metropolitan area of Curitiba, presenting a high consumption of electricity for 2050, which exceeds 14 TWh. In addition, the GCPVS power to be implemented in each mesoregion of Paraná for 2050 was pointed out. In this way, the mesoregions deserve attention for investments in electricity generation, and consequently also indicates that transmission and distribution works should be implemented to meet the demand of the coming decades.

\section{REFERENCES}

1. Scott W. Education and sustainable development: challenges, responsibilities, and frames of mind. The Trumpeter. 2002; 18(1): 22-34.

2. Boza MMC, Calgaro C, Lucca MF. Sustentabilidade, desenvolvimento sustentável e ecodesenvolvimento: Um projeto para uma justiça política-social?. Âmbito Jurídico [Internet]. Rio Grande, 2011 [cited 2016 Apr. 30]. Available from: http://www.ambitojuridico.com.br/site/index.php?artigo_id=9166\&n_link=revista_artigos_1 eitura

3. United Nations. General Assembly. 42 session. Development and International Economic Co-Operation: Environment. Our Common Future. 1987 [cited 2016 Sep. 02]. Available from: https://ambiente.files.wordpress.com/2011/03/brundtland-report-our-common-futur e.pdf.

4. Solo RA, Georgescu-Roegen N. Arithmomorphism and Entropy. 1974.

5. Empresa de Pesquisa Energética. Demanda de Energia 2050. Série Estudos da Demanda de Energia. Nota Técnica DEA 13/15. Rio de Janeiro, 2016.

6. Tiepolo GM. Estudo do Potencial de Geração de Energia Elétrica através de sistemas fotovoltaicos conectados à rede no Estado do Paraná. 2015. 228 f. Thesis. Pontifícia Universidade Católica do Paraná, Curitiba, 2015.

7. Ministério de Minas e Energia. Resenha Energética Brasileira. Brasília: MME, 2016.

8. Agência Nacional de Energia Elétrica. Atlas de Energia Elétrica do Brasil. Parte I: Energia no Brasil e no Mundo. 3 ed. Brasília, 2008 [cited 2016 Aug. 15]. Available from: http://www2.aneel.gov.br/arquivos/pdf/atlas_par1_cap1.pdf

9. Tiepolo GM, Castagna AG, Canciglieri JR O, Betini R. Fontes Renováveis de Energia e a Influência no Planejamento Energético Emergente no Brasil. VIII Congresso Brasileiro de Planejamento Energético. Curitiba: CBPE, 2012.

10. Fundação Instituto Brasileiro de Geografia e Estatística. Divisão Regional do Brasil em Mesorregiões e Microrregiões Geográficas. Volume I. Rio de Janeiro: IBGE, 1990 [cited 2017 Apr. 06]. Available from: https://biblioteca.ibge.gov.br/visualizacao/monografias/G EBIS\%20-\%20RJ/DRB/Divisao\%20regional_v01.pdf 
11. Instituto Paranaense de Desenvolvimento Econômico e Social. Leituras Regionais: Mesorregiões Geográficas Paranaenses: Sumário Executivo. Curitiba: IPARDES, 2004.

12. Programa das Nações Unidas para o Desenvolvimento. Atlas do Desenvolvimento Humano nas Regiões Metropolitanas Brasileiras. Brasília: PNUD, Ipea, FJP, 2014 [cited 2017 Apr. 06]. Available from: http://www.atlasbrasil.org.br/2013/data/rawData/publicacao_atlas_ rm_pt.pdf

13. Instituto Paranaense de Desenvolvimento Econômico e Social. Anuário Estatístico do Estado do Paraná. 2010 [cited 2017 Mar. 09]. Available from: http://www.ipardes.pr.gov.br/anu ario_2010/

14. Instituto Paranaense de Desenvolvimento Econômico e Social. Projeção Da População Total Dos Municípios do Paraná para o Período 2016-2030 - Alguns Resultados [cited 2017 May 09]. Available from: http://www.ipardes.pr.gov.br/pdf/ indices/projecao_populacao_Parana_ 2016_2030_set.pdf

15. Instituto Paranaense de Desenvolvimento Econômico e Social. Anuário Estatístico do Estado do Paraná - 2013 [cited 2017 Mar. 09]. Available from: http://www.ipardes.pr.gov.br/anuari o_2013/index.html

16. Instituto Paranaense de Desenvolvimento Econômico e Social. Anuário Estatístico do Estado do Paraná - 2015 [cited 2017 Mar. 09]. Available from: http://www.ipardes.pr.gov.br/anuari o_2015/index.html

17. Barroso LC. et al. Cálculo Numérico (Com Aplicações). 2nd ed. São Paulo: Harbra, 1987.

18. Ruggiero MAG, Lopes VLR. Cálculo Numérico: aspectos teóricos e computacionais. 2nd ed. São Paulo: Makron Books, 1996.

19. Instituto Paranaense de Desenvolvimento Econômico e Social. Comunicado para o Planejamento. 2013 [cited 2017 Jun. 13]. Available from: http://www.ipardes.gov.br/bibliote ca/docs/Comunicado_Planejamento_27.pdf 